مقاله يزوهشى

مجله دانشعاه علوم :ز شكى رفسنجان

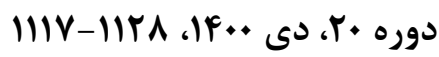

مقايسه هزينههاى اعمال جراحى كلوبال با تعرفهایى مصوب دولتى در بيمارستان تكى

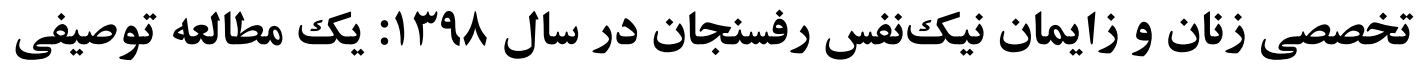

على زارع عسكرى'، مجيد مير محمدخانى"، محمدرضا شهاب"، عباسعلى ابراهيميان

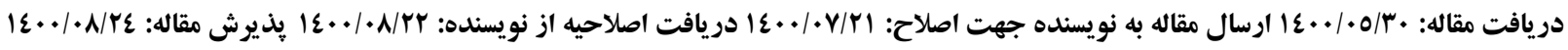

زمينه و هدف: محاسبه هزينههاى خدمات بسترى مشمول تعرفه كلوبال و مقايسه آن با تعرفه مصوب در بيمارستانها از نظر سود و زيان بيمارستانها بسيار حائز اهميت است. اين يزوهش با هدف تعيين و مقايسه هزينه صورت حسابهاى اعمال اعمال جراحى كلوبالبا تعرفهاى مصوب آنها در بيمارستان تك تخصصى زنان و زايمان نيكنفس دانشكاه علوم يزشكى رفسنجان انجام ترفت.

مواد و روشها: در اين مطالعه توصيفى، جامعه يزوهش شامل كليه صورت حسابهاى موجود در يروندههاى بسترى مشمول

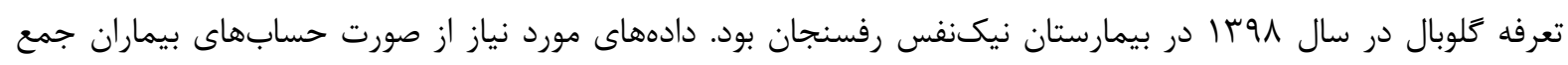

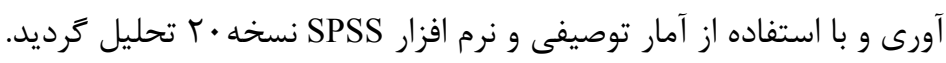

يافتهها: در سال هوبا از مجموع خدمات بسترى مربوط به كروه زنان و زايمان، 4 خدمت مشمول تعرفه كلوبال انجام شد.

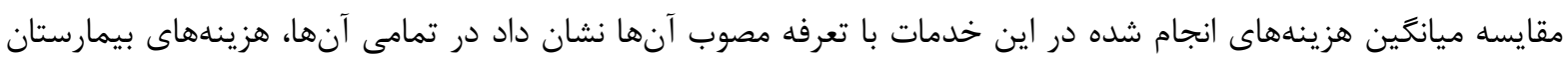

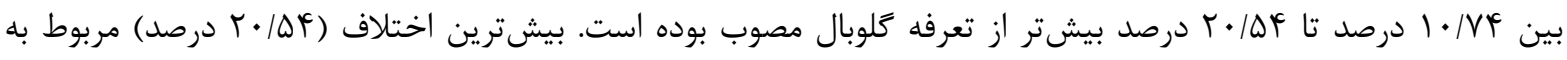

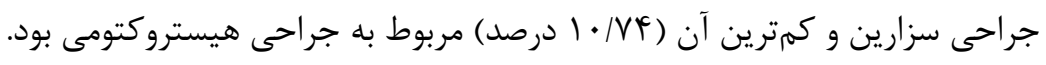

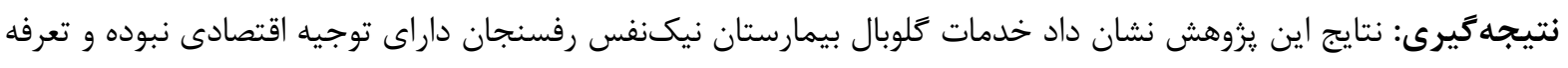

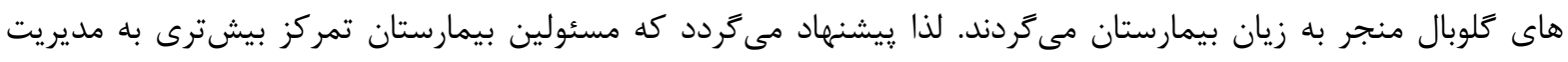

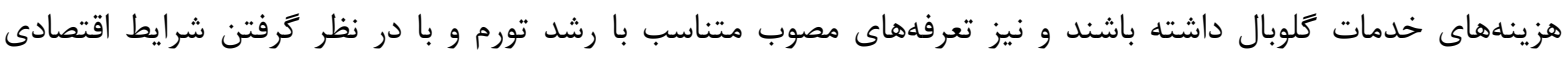
بيماران، مورد بازبينى قرار كيرند.

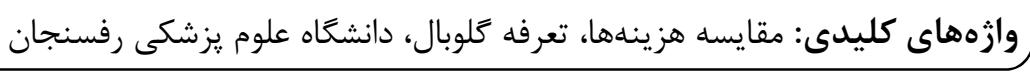

1- دانشجوى دكتراى تخصصى مديريت خدمات بهداشتى و درمانى، واحد سمنان، دانشكاه آزاد اسلامى، سمنان، ايران

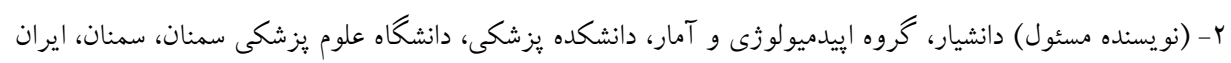

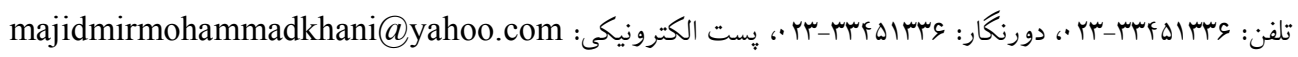

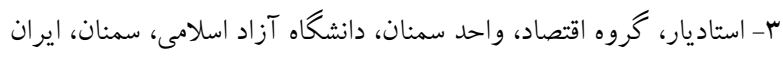

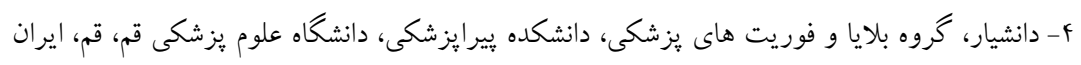


هاى مناسب در راستاى افزايش كارآيى، اثربخشى، بهبود مقدمه

كيفيت خدمات و در نهايت، رضايتمندى مشتريان را به همراه داشته باشد [11]]. يكى از عوامل مههم افزايش هزينه هاى بيمارستانى، خدماتى است كه ارائه مى بنابراين، اداره اقتصادىتر بيمارستانها براى جلوگيرى از هدر رفتن منابع بسيار ضرورى است [IT]. Olyan Ajam بيمارستانى و مقايسه آنها با هزينههاى گلوبال به اين نتيجه رسيدند كه فرآيند راهبردى مديريت هزينه بيمارستان شامل شناسايى كانونهاى هزينهبر، فرهنگسازى مديريت هزينه، وضع قوانين و مقررات داخلى، نظارت و كنترل، استقرار سيستم هزينهيابى، تشكيل كارَروه و برنامهريزى عملياتى است [r]. Ghiyasvan و همكاران از طريق مقايسه قيمت واقعى با تعرفههاى مصوب خدمات در مراكز آموزشى درمانى وابسته به دانشگاه علوم يزشكى اردبيل دريافتند كه تفاوت معنادارى بين قيمت واقعى خدمات راديولوزى و تعرفههاى مصوب آن وجود دارد [^]. مطالعه Ergun در تركيه نشان داد كه هزينه آزمايشهاى ياتولوزى در تعرفه بهداشت و درمان با واقعيت تفاوت معنادارى دارد [9]. Chatruz و همكاران در مقايسه هزينه صورت حسابهاى اعمال جراحى كلوبال با تعرفههاى مصوب در بيمارستانهاى دانشگاه علوم يزشكى تهران دريافتند كه هزينه اعمال جراحى بين r تا باس درصد بيشتر از تعرفه كلوبال مصوب بود. بيشترين اختلاف (TIM درصد) مربوط به ترميم تيغه بينى با يا بدون كاشت غضروف (سيتويلاستى) بود [rا]]. Arab و همكاران با مقايسه هزينههاى اعمال جراحى عمومى (كلوبال) در بين 
بيمههاى مكمل، يروندههايى كه داراى اعمال جراحى توام بودند و يروندههايى كه در ثبت دادهها داراى اشكال بودند. براى جمعآورى دادهها، به واحدهاى درآمد و مدارك يزشكى بيمارستان مراجعه و دادههاى مربوط به صورت حساب

بيماران از سيستم اطلاعات بيمارستان ( Hospital (HIS) Information System )، استخراج شد. ابزار استفاده شده براى جمع آورى دادهها، جك ليستى متناسب با اهداف يزوهش و منطبق با فهرست تعرفهاى مصوب دولتى در خدمات بسترى گلوبال، طراحى شد. در اين يزوهش روش كردآورى، كذشتهنكر به صورت كتابخانهاى و فيش بردارى از منابع و مدارك موجود در بيمارستان نيك نفس دانشعاه علوم يزشكى رفسنجان بـوده و با استفاده از نشريات و منابع اطلاعاتى موجـود در آن بيمارستان، دادهاى مورد نياز جمع آورى گرديد. ابزار كردآورى اطلاعات شامل موارد ذيل بود:

الف: فيشبردارى از بانكهاى اطلاعاتى و اسناد و مدارى

$$
\text { موجود در بيمارستان نيك نفس رفسنجان }
$$

ب: بخشنامهها و دستورالعملهاى صادره توسط وزارت بهداشت و درمان، آموزش يزشكى و صورت حسابهاى مالى بيماران

ج: صورتحسابهاى موجود در يروندهاى اعمال جراحى كلوبال بيماران در بيمارستان نيك نفس در سال يوس| تعرفه خدمات تشخيصى - درمانى: مجمـوع مبلغسى كه سازمانهاى بيمهاى و مشتريان در هنعام اسـتفاده از خدمات به ارائهكنندكان خدمت مىيردازند. تعرفههـا در بخـش خصوصى شـامل سـود سـرمايه و اسـتهلاك
بيمارستانهاى ملكى تأمين اجتماعى استان تهران دريافتند كه تفاوت معنادارى بين اين هزينهها وجود ندارد [If]. با مديريت بهينه هزينهها از طريق مقايسه هزينهاى اعمال جراحى كلوبال با تعرفههاى مصوب مىتوان انخيزه ارائه كنـــدمان خــدمات بــراى افزايش غيرمنطقى خدمات و به تبـع آن افزايش هزينـههـاى درمانى را كنترل نمود [10]. از اين رو، مطالعه حاضر با هدف تعيين و مقايسه هزينههاى واقعى اعمال جراحى كلوبال با تعرفهاى مصوب در بيمارستان تك تخصصى زنان و زايمان نيكنفس

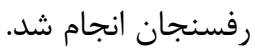

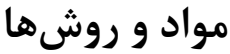

اين مطالعه از نوع توصيفى است كه در آن هزينه اعمال جراحى گلوبالبـر اسـاس فهرست تعرفههاى مصوب دولتىى، در بيمارسـتان تك تخصصى زنان و زايمان نيك نفس شهرستان رفسنجان در سال 91 ا محاسبه گرديد. مطالعه حاضر با كد اخلاق IR.IAU.SEMNAN.REC.1399.002 در كميته اخلاق دانشخاه علوم يزشكى سمنان تصويب شد. جامعه آمارى شامل صورت حسابها و يروندهاى بسترى مشمول تعرفه خدمات تشخيصى و درمانى كلوبال كه در سال \وسا به مراجعين بيمارستان نيك نفس ارائه كرديد، بود. اين خدمات شامل زايمان بىدرد، زايمان طبيعى، سر كلاز، سزارين، سقط عفونى و هيستروكتومى است. معيار ورود، وجود نمونه كافى (حداقل • ا صورت حساب) از خدمات شش كانه فوق بود [ [1 I]. معيارهاى خروج شامل يروندهايى كه با تعرفه سال 19זן محاسبه نشده بودند؛ يرونده بيماران آزاد يا داراى 


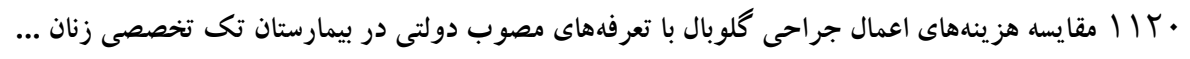

(NST))، و فيزيوترايى) بود. روايى صورى جك ليست با نظر • ا تن از كارشناسان بيمارستان (سه نفر كارمند از واحدهاى در آمد و مدارك يزشكى، سه كارشناس بيمه، دو نفر كارمند واحد ترخيص، يك نفر دكتراى اقتصاد سلامت و يك نفر دكتراى آمار) تاييد گرديد. اطلاعات مربوط به هزينه تعرفه كلوبال از بخشنامه سال |qجا شوراى عالى بيمه در مورد

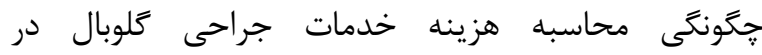
بيمارستان درجه يك به دست آمد [11]. و از فرمول (1) براى ميانگَين هزينه انجام شده براى يك خدمت كلوبال استفاده شد.

جعداد هزئنه هاى آن خدمت در طول سال

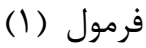

دادههاى جمعآورى شده با استفاده از آمار توصيفى و آمار استنباطى در نرم افزار SPSS نسخه •ب تحليل گرديد. در آمار توصيفى از شاخص ميانگين و درصد و در آمار استنباطى از آزمون مقايسه زوجى براى مقايسه ميانگين هزينههاى اعمال جراحى كلوبال با تعرفههاى مصوب كلوبال استفاده شد. سطح معنادارى آزمون هـ • در نظر كرفته شد.

\section{نتايج}

محاسبه هزينههاى اعمال جراحى با تعرفه گلوبال در سال 91٪| در بيمارستان نيكنفس رفسنجان و همرجنين محاسبه ميانگين هزينههاى هر يك از خدمات مورد بررسى بيانگر آن است كه هزينههاى تمامى خدمات ارائه شده بيشتر از تعرفه كلوبال مصوب آنها مىباشد. هزينهاى اعمال جراحى كَلوبالدر بيمارستان تك تخصصى نيك نفس
كالاهاى سرمايهاى نيز مى شود، در حالى كه در بخش دولتى سود سرمايه و استهلاك كالاهاى سـرمايهاى در تعرفه هاى دولتى منظور نمىشود. منظــور از تعرفـه در اين يزوهش تعرفـهـــاى خـدمات تشخيصى - درمـانى مصوب هيئت وزيران و ضريب (k) آنها در بخش دولتى مىباشد ضـــريب تعرفـــهـ (k): ارزشهـــاى نسـبى خــدمات يزشـكى، معيارهـايى جهـت تجزيـه و تحليـل اقـدامات يزشكى و تعيين بهاى آنها مسىباشـد. در حـال حاضـر ارزش نسبى با توجـهـ بـهـ متغيرهـايى همجــون زمـان و مهارت لازم براى ارائه خـدمت، وخامـت حسال بيمـار و خطراتى كه بيمار و يزشك را تهديد مسىكنـد، تعيسين مى شود. اصطلاحاً اين ارزش نسبى، بـر حسب تعـداد ضريب ثابتى به نام ضـريب تعرفـه (k) بــراى كروههــاى مختلــف جراحسى، بيهوشــى، داخلــى، دندانيزشــكى و فيزيوترايى تعيين مى گردد. مبلغ اين ضريب هـر سـاله توسط هيئت محترم وزيران تعيين و تصويب مى گـردد [91]. جك ليست استفاده شده در اين يزوهش شامل اطلاعات يذيرش بيمار (شماره يرونده، تاريخ بذيرش، نوع بيمه درمانى و تشخيص يزشك) و اطلاعات مربوط به هزينههاى اعمال جراحى كلوبال (هزينه تخت، ويزيت، مشاوره، حق الزحمه بيهوشى، هزينه كمك جراح، حق الزحمه جراحى، اتاق عمل،

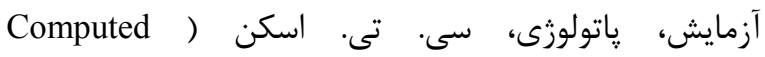
(C.T. scan) tomography scan لوازم مصرفى، دارو، تست نوار قلب جنين Non Stress Test 
هزينههاى واقعى خدمات و تعرفه كلوبال مصوب آنها مربوط

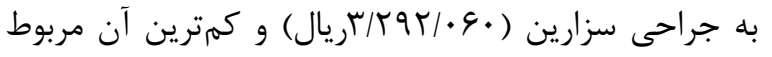

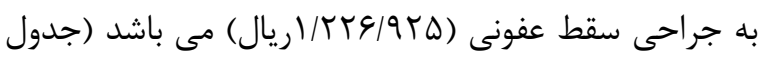

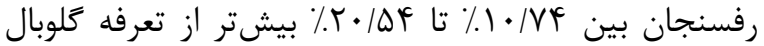
مصوب بوده است. بيشترين اختلاف (AF • م درصد) مربوط به جراحى سزارين و كمترين آن (VF/ • آدرصد) مربوط به جراحى هيستروكتومى بود كه به زيان بيمارستان تمام شد. همجنين بيشترين ميانگين ريالى اختلاف قيمت ميان

جدول ا - فهرست اعمال جراحى با هزينه صورتحساب بيشتر از تعرفه تلوبال مصوب در بيمارستان تك تخصصى زنان و زايمان نيك نفس رفسنجان

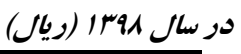

\begin{tabular}{|c|c|c|c|c|}
\hline ميانغين درصد اختلاف هزينه انجام & شده با تعرفه مصوب عَلوبال & ميانغين هز ينه & اعمال جراحى تعلوبال & خدمت بلوبال \\
\hline$\% 1 \Delta / 9 \mu$ & $r / 4 \cdot / q \cdot q$ & $10 / 1 \cdot \cdot 1 / \cdot 9$ & $\mid r / \cdot \Delta q / q .$. & زايمان بىدرد \\
\hline r & I/AৎN/V৭D & ه $|r / r| \cdot / r 9 \Delta$ & $\| / \kappa+1 / \Delta \ldots$ & زايمان طبيعى \\
\hline$\% 19 / 99$ & $|/ K T G| \cdot r \mid$ & $N / \cdot V Y / \cdot r I$ & g|V|q|... & سر كلاز \\
\hline$\% \cdot r \cdot \mid \Delta F$ & T/TqT/.G. & $19 / \pi r \cdot / r g$. & $|q| \cdot Y N / Y \ldots$ & سزارين \\
\hline$\%|\wedge / 4|$ & I/rTG/9TD & V/AM৭/Gra & 9/90N/qrq & سقط عفونى \\
\hline$\% 1 \cdot / V F$ & T/FFr/FqV & $r \Delta / r \cdot r / T q V$ & $r T / V \Delta \Lambda / \Lambda \ldots$ & هيستر وكتومى \\
\hline
\end{tabular}

داده است. بيشترين و كمترين ميزان اين اختلاف در جراحى سزارين به ترتيب مربوط به ماه هاى خرداد

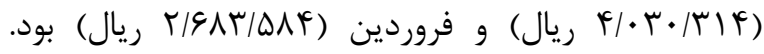
بيشترين و كمترين ميزان اختلاف قيمت سقط عفونى به

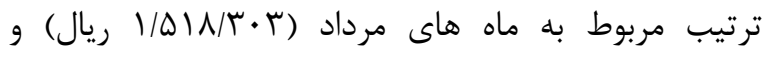
ارديبهشت (سMNRM V ريال) اختصاص داشت. و در نهايت، بيشترين و كمترين ميزان اختلاف ميان هزينه هاى جراحى هيستروكتومى با تعرفه كلوبال مصوب آن به ترتيب در ماه

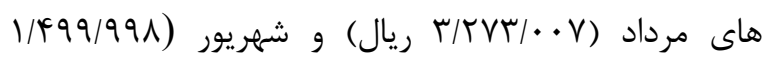
ريال) اتفاق افتاده است (جدول r).
بررسى افزايش / كاهش ريالى هزينه هاى خدمات ارائه شده مشمول تعرفه گَلوبال، در ماه هاى مختلف سال در مركز آموزشى درمانى تك تخصصى نيك نفس رفسنجان نشان داد كه زايمان بىدرد بيشترين ميزان اختلاف را در ماه دى (· . F/9TI/G ريال) و كمترين ميزان را در ماه

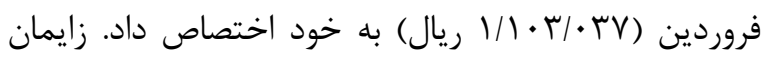
طبيعى بيشترين ميزان اختلاف را در ماه آذر (AF/DFA)

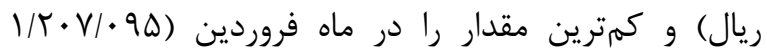
ريال) به خود اختصاص داد. بيشترين و كمترين ميزان اختلاف قيمت سركلاز به ترتيب در ماههاى بهمن

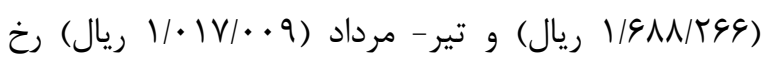




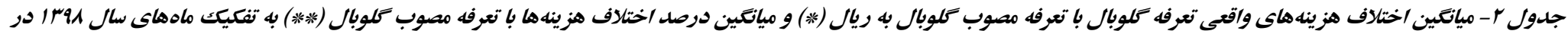
بيمارستان تك تخصصى زنان و زايمان نيكنتفس رفسنجان

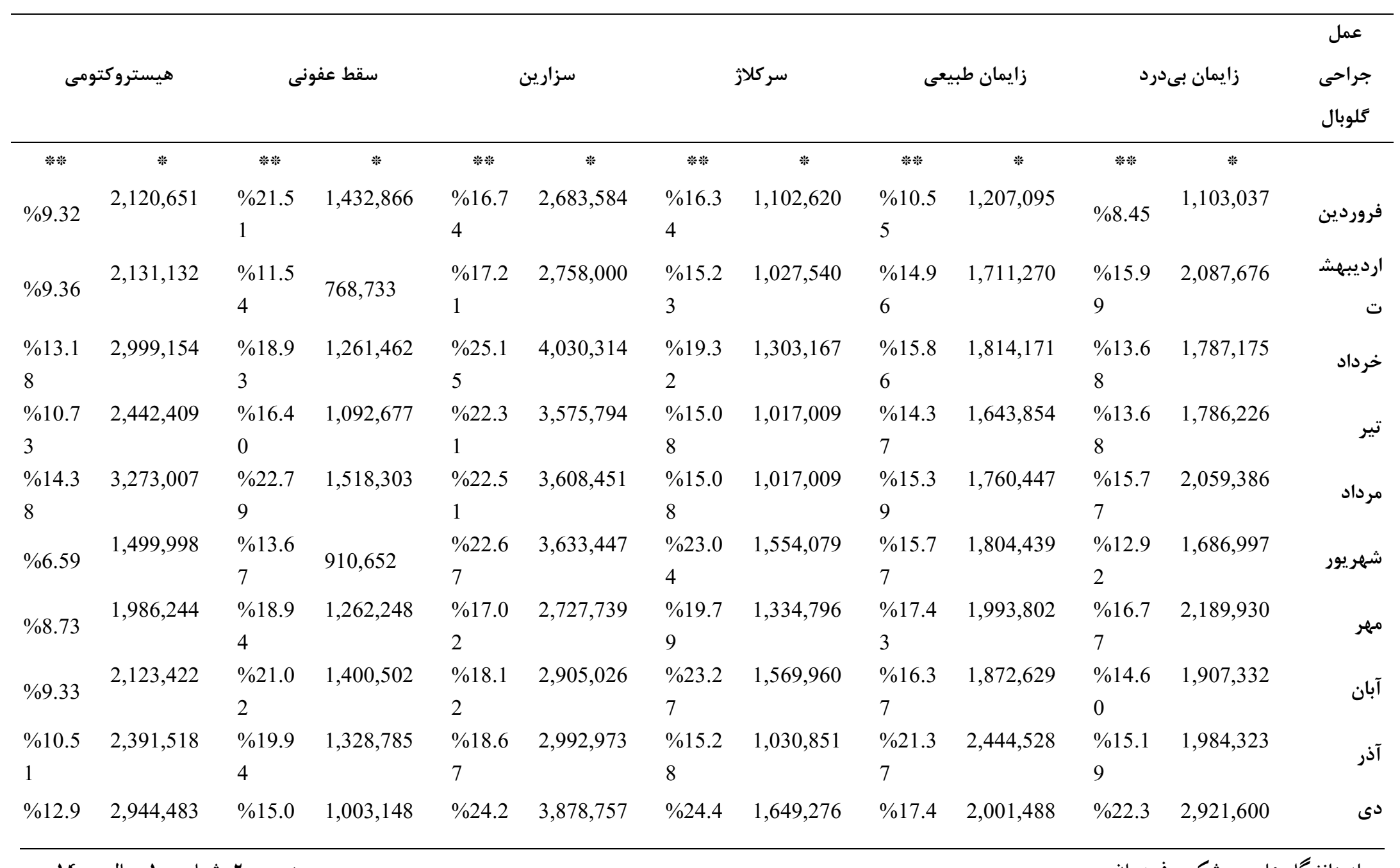

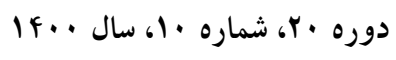


$11 \pi r$

على زارع عسكرى و همكاران

\begin{tabular}{|c|c|c|c|c|c|c|c|c|c|c|c|c|}
\hline 4 & & 6 & & 0 & & 5 & & 9 & & 7 & & \\
\hline$\% 14.3$ & $3,265,924$ & $\% 21.8$ & $1,457,789$ & $\% 23.2$ & $3,729,582$ & $\% 25.0$ & $1,688,266$ & $\% 19.4$ & $2,228,786$ & $\% 19.9$ & $2,608,986$ & \\
\hline 5 & \multirow{3}{*}{$2,144,022$} & 8 & \multirow{3}{*}{$1,285,940$} & 7 & & 3 & & 8 & & 8 & & \\
\hline \multirow[t]{2}{*}{$\% 9.42$} & & $\% 19.3$ & & $\% 18.6$ & \multirow[t]{2}{*}{$2,981,058$} & $\% 23.9$ & \multirow[t]{2}{*}{$1,617,796$} & $\% 16.9$ & \multirow[t]{2}{*}{$1,943,032$} & $\% 18.1$ & \multirow[t]{2}{*}{$2,368,244$} & \\
\hline & & 0 & & 0 & & 8 & & 8 & & 3 & & \\
\hline
\end{tabular}


عمل جراحى كورتاز، هزينه پاتولوزى از 9 هزار ريال تا •r

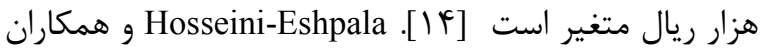
در سال ₹q廿ا با مقايسه هزينه يروندههاى بسترى در نظام كلوبال با سيستم بازيرداخت كذشته نكر دريافتند كه بيشترين ميزان يروندههاى كلوبال به گروه زنان و زايمان تعلق داشت و در \&1 درصد يروندها، هزينه عمل جراحى با كلوبال به سود بيمارستان بوده است [IV] Chatruz و همكاران نيز در مطالعهاى مشابه در بيمارستانهاى وابسته به دانشعاه علوم يزشكى تهران دريافتند كه بيشترين ميزان موارد كلوبال (4 د درصد) متعلق به گروه زنان و زايمان بود و در ه9 درصد يروندهها، احتساب هزينه عمل جراحى با كلوبال به سود بيمارستان بوده است كه YV درصد از اين اختلاف هزينهها معنادار بودند [rا]. مطالعه Ergun و همكاران در تركيه نشان داد كه تفاوت بين هزينه اعمال جراحى كلوبال يرداختشده از سوى سازمانهاى بيمهكر به بيمارستانها با هزينههاى واقعى آنها كاهش يافته است. هم جنين، تفاوت جشمگيرى بين هزينههاى گلوبال اعمال جراحى با هزينه واقعى آنها به جشم مى خورد (هزينههاى واقعى بسيار بيشتر از هزينههاى كلوبال مى باشد) [9]. بر اساس يافتههاى يزوهش Sarlak و همكاران، تعرفههاى مصوب وزارت بهداشت جبرانكننده بهاى تمام شده يك واحد خدمات جراحى در بيمارستانهاى دانشگاه علوم يزشكى استان قم نمىباشد و انحراف قابل توجهى در اين زمينه وجود دارد. به اين معنى كه هزينه تمام شده اين خدمات بيشتر از تعرفه مصوب كلوبال است [1/]. نتايج مطالعه Ebrahimipour و همكاران در بيمارستان امام رضا
مقايسه هزينههاى اعمال جراحى كلوبال با تعرفههاى مصوب دولتى در بيمارستان تك تخصصى زنان و زايمان نيك نفس رفسنجان با استفاده از مقايسه زوجى نشان داد كه هزينه واقعى خدمات بسترى به ميزان بوع/بr•/ץ ريال بيشتر از تعرفه گلوبال است و با توجه به نتيجه آزمون، اين

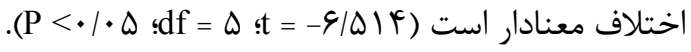
بحث نتايج مطالعه حاضر نشان داد كه تفاوت معنادارى ميان هزينه هاى خدمات مشمول تعرفه گلوبال با تعرفه گلوبال مصوب آنها در بيمارستان تك تخصصى زنان و زايمان نيك نفس رفسنجان وجود دارد كه منجر به زيان بيمارستان شده است. مقايسه تعرفههاى مصوب گلوبال با هزينههاى واقعى خدمات ارائه شده ميزان زيانهاى وارده به سازمانهاى خدمات درمانى را در اين زمينه آشكار مىسازد. در توجيه اين نتيجه، يكى از دلايل احتمالى را مىتوان به نوسانات شديد نرخ تورم و عدم اعمال آن در تعرفههاى مصوب مرتبط دانست. در مطالعه Arab و همكاران مشخص شد كه مديريت هزينههاى بسترى توسط بيمارستانها مغفول مانده است به طورى كه دامنه تغييرات اجزاء هزينهاى آنها عليرغم يكسان بودن شرايط، دستورالعملها و تعرفهها بسيار متغير است. به عنوان مثال، متوسط هزينه صورت حساب يك عمل جراحى آياندكتومى از | بيمارستانهاى ملكى تأمين اجتماعى استان تهران متغير است و متوسط اين شاخص اسوا هزار ريال برآورد كرديده است. همزجنين در حيطه خدمات ياراكلينيكى، به ازاء هر 
مطالعه Madani و همكارش كه در سال 1199 در بيمارستان امين اصفهان انجام گرفت در مغايرت با يافتههاى يروهش حاضر نشان داد كه ميانگين هزينههاى صورت حساب بيماران در عمل سزارين، كمتر از تعرفه مصوب حلوبال بود. بيشترين اختلاف ميانگين مربوط به عمل آياندكتومى (DV درصد) و كمترين مربوط به عمل فتق (9/ • درصد) بود [·r]. Aboutorabi و همكارش با مقايسه تعرفههاى كلوبال اعمال جراحى و هزينههاى واقعى در مركز آموزشى درمانى حضرت رسول اكرم تهران دريافتند كه بيشترين فراوانى جراحىهاى گلوبال مربوط به جراحى جشم بود. مهمترين تفاوت بين تعرفه كلوبال و هزينه واقعى نيز مربوط به جراحى حشم بود. به طور كلى، صورتحسابهاى واقعى بيمارستان بسيار بيشتر از تعرفههاى مصوب براى جراحىهاى كلوبال بود [r/]. مطالعه حاضر محدود به بيمارستان نيك نفس رفسنجان و مقايسه هزينههاى اعمال جراحى گلوبال با تعرفههاى مصوب مىباشد. از اين رو ي קيشنهاد مى گردد كه در مراكز درمانى ديكر نيز مورد مطالعه قرار ترفته و ميزان اختلاف را در آنها نيز مورد بررسى قرار داد. زيرا نتايج بدستآمده قابل تعميم نيستند و ممكن است كه بنا بر شرايط هر مركز اعم از تعداد خدمات قابل ارائه، مدت اقامت بيماران و تعداد يروندههاى هر عمل كلوبال، متفاوت باشند. يكى از محدوديتهايى كه ممكن است بر نتايج مطالعه اثركذار باشد عدم ثبت و نكَهدارى دقيق اسناد و يروندهها است. بنابراين لازم است كه مراكز درمانى در نتحهدارى اسناد و مدارك بيماران مراقبت و

$$
\text { تمهيدات لازم در نظر بخيرند. }
$$

در مشهد نشان داد كه در برخى از جراحىها مانند هيستركتومى، زايمان طبيعى، سى تى اسكن، عمل لوزه، ترميم فتق و آيانديس، هزينه خدمات بالاتر از ميانگين قيمت كلوبال آنها بود و در جراحى آناستوموز شريانى، كوله سيستكتومى، تميانويلاستى و تيروئيدكتومى كمتر از ميانگين قيمت كلوبال بود. نتايج مطالعه آنها نشان داد كه اكثر بيمارستانها قيمت كلوبال اعمال جراحى را كاملاً ناديده كرفتهاند [ [1]. نتايج مطالعه حاضر نشان داد كه بيشترين اختلاف ميان قيمت واقعى اعمال جراحى با تعرفه گلوبال مربوط به سزارين

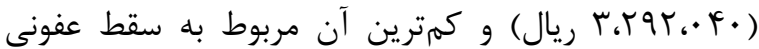

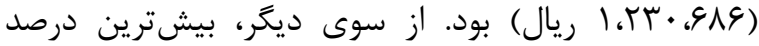
اختلاف هزينه صورت حساب با تعرفه گَلوبال مصوب مربوط به خدمات سزارين و سقط عفونى و كمترين آن متعلق به هيستروكتومى بود. در اين راستا، Chatruz و همكاران دريافتند كه هزينه اعمال جراحى در بيمارستانهاى علوم يزشكى دانشخاه تهران بين ץ تا ץاس درصد بيشتر از تعرفه كلوبال مصوب بود. بيشترين اختلاف (YIM درصد) مربوط به تيغهى بينى با يا بدون كاشت غضروف (سيويلاستى) بود [11]]. در مطالعهاى كه توسط Pirzadeh و همكارش انجام شد هزينهى عمل جراحى گلوبال تونسيلكتومى با تعرفه مصوب در بيمارستانهاى امام خمينى و فاطمى شهر اردبيل مورد مقايسه قرار گرفت و نتايج مطالعه نشان داد كه تعرفهى يرداختى بيمه عمل جراحى تونسيلكتومى در مقايسه با كل هزينه يرداختى از طرف بيمارستان خيلى يايين است و بيمارستانها متضرر مىشوند [ [19]. يافتهاى 


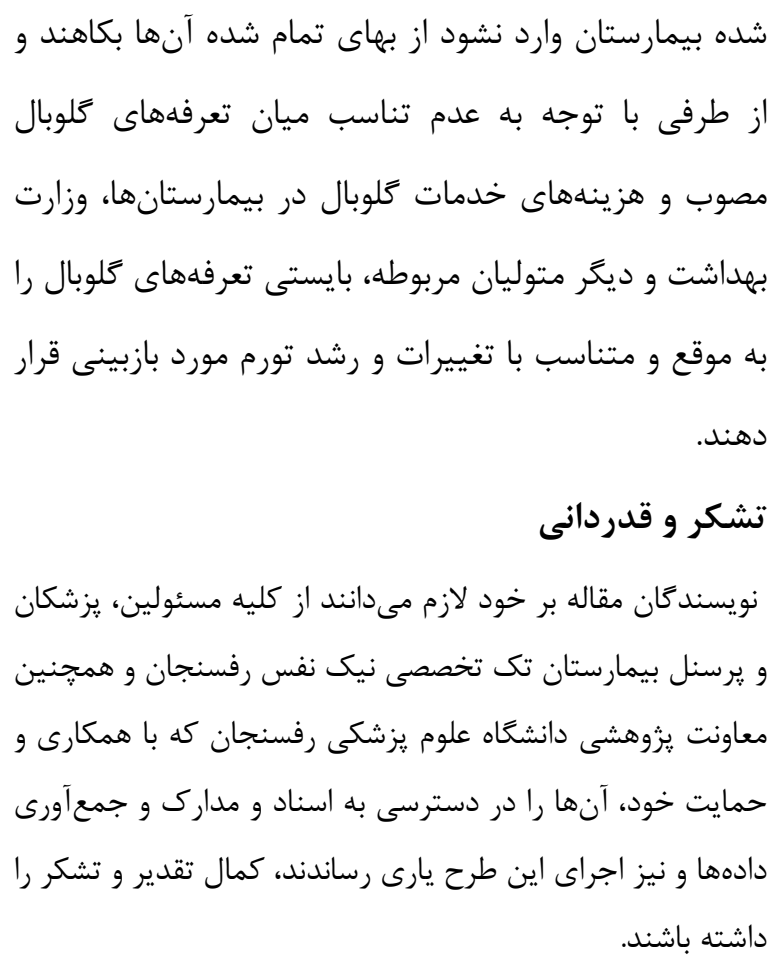

\section{References}

[1] Ebrahimipour H, Pourahmadi E, Badiee Aval S, Rezazadeh A. Comparison of the Charges of 10 Selected Surgeries in Imam Reza Hospital with their Official Global Prices. JRH 2020; 10(5): 319-28. [Farsi]

[2] Olyan Ajam S, Ghasemizad A, Gholtash A. Identifying the main components of the hospital costs management process. JHA 2019; 22(3): 40-55. [Farsi]
[3] Lagomarsino G, Garabrant A, Adyas A, Muga R, Otoo N. Moving towards universal health coverage: health insurance reforms in nine developing countries in Africa and Asia. The Lancet 2012; 38(5): 933-43.

[4] Mirzaei A, Gomar A, Ebrahimi G, Tafazoli M, Soltani L, Fekri $\mathrm{Z}$ et al. Investigating the relationship between the implementation of the payment system of related diagnostic groups 
and the reduction of treatment costs in a military hospital. NPWJM 2018; 6 (21): 53-59. [Farsi]

[5] Mirzaei H, Naseri G, Rezaee R, Mohammadi M, Banikazemi Z, Mirzaei HR, et al. Curcumin: A new candidate for melanoma therapy? Int $J$ Cancer 2017; 23(2): 184. [Farsi]

[6] Rathi A, Dusti F, Reyhani Yasawoli A. Outsourcing challenges of providing health services to the private sector from the perspective of the staff of Mashhad University of Medical Sciences. JSS 2018; 13(4): 117-34. [Farsi]

[7] Amiresmaeili Mohammad R, Imani E, Jahad Sarvestani A. Evaluation of Terminal Life Cost for Patients Admitted in Teaching Hospitals Affiliated with Kerman University of Medical Sciences in 2014. JHBR 2015; 1(2): 133-43. [Farsi]

[8] Ghiyasvan H, Zandiyan H, Moghadam TZ, Naghdi S. Cost of radiology services using the activity based costing (ABC) method. Payesh 2013; 34(6): 595-605. [Farsi]

[9] Ergun F, Agirbas I, Kuzu I. Activity-based costing for pathology examinations and comparison with the current pricing system in Turkey. TJP 2013; 29(1): 1-14.

[10] Shahrjerdi R, EbrahimAbadi GR, Shahbazi S. Evaluating the cost of quality and selecting the appropriate option for cost reduction using fuzzy ahp and fuzzy topsis models (case study: the water and wastewater company of Markazi province). JWSD 2018; 4(1): 13-22. [Farsi]

[11] Haddad M. Viewpoints of employed nurses in hospitals of Birjand city regarding existing barriers in patient education. MCJ 2011;8(1): 297.

[12. Rezapour A, Ebadi Fard Azar F, Arabloo J. Cost Analysis in Cost Centers of $\mathrm{Bu}$ Ali Sina Teaching Hospital of Qazvin University of Medical Sciences. Teb vaTazkiye 2012; 2: 31-9. [Farsi]

[13. Chatruz A, Javadinasab H, Amini MK, Biglar M, Goudarzi N, Javad J. A comparison of the cost of global surgery bills with approved tariffs in hospitals affiliated to Tehran University of Medical Sciences. JPS 2015; 9(1): 67-80. [Farsi]

[14] Arab M, Zeraati H, Ravangard R, Gholinejad A, Rasooli A. Comparing global-operations reimbursements with their actual costs in the Cancer Institute, Tehran. JSPH 2008; 16(1): 843. [Farsi]

[15] Donald G, Scott S, Broadfield L, Harding C, Meade A. Optimizing patient education of oncology medications: A descriptive survey of 
pharmacist-provided patient education in Canada. JOPP 2019; 25(2): 295-302.

[16] The high Council of the Medical Services Insurance. Global surgical approved tariffs. Available at: http://www.mums.ac.ir/shares/ darman/specialsick/Darman-Eghtesaddarman-

Global.pdf. 2012.

[17]Hosseini-Eshpala R, Khorramy F, Baniasadi T, Azarmehr N, Mohammady F, Hayavy Haghighi $\mathrm{MH}$, et al. The Comparison of the cost of patient records in a global system with corresponding retrospective reimbursement system: a case study in Iran. JMMIS 2015;1(1): 65-74. [Farsi]

[18] Sarlak N, Ghanbari AM, Moharreri Z. Verification Approved Tariffs of Medical Services in Comparison with the Cost of these
Services in Qom Medical University by $\mathrm{ABC}$ Approach. JGA 2015; 2(1): 17-30. [ Farsi]

[19] Pirzadeh A, Amani F. Estimate total costs for tonsil surgery in Emam and Fatemi hospitals in Ardabil city and compare with global cost of insurance organization. Available at: http://eprints.arums.ac.ir/3224/. 2011. [Farsi]

[20]Madani SM, Taji M. Calculate the cost of selected global surgical operations and comparison with the approved tariffs in Amin hospital in Isfahan. Homa-ye-Salamat 2010; 7(3): 6-9. [Farsi]

[21] Aboutorabi A ,Radinmanesh M. A comparison of global surgery tariffs and the actual cost of bills at Hazrate Rasoole Akram educational and medical center. CERA 2020; 18(1): 1-10. [Farsi] 


\title{
Comparison of Global Inpatient Services Costs with Approved Tariffs in Niknafs Obstetrics and Gynecology Hospital in Rafsanjan in 2019: A Descriptive Study
}

\author{
A. Zare Askari' ${ }^{1}$ M. Mir Mohammadkhani ${ }^{2}$, M. R. Shahab ${ }^{3}$, A. A. Ebrahimian ${ }^{4}$ \\ Received: 21/08/21 Sent for Revision: 13/10/21 Received Revised Manuscript: 13/11/21 Accepted: 15/11/21
}

Background and Objectives: It is very important to calculate the costs of inpatient services covered by the global tariff and compare it with the approved tariff in hospitals in regard to the financial profit and loss. In this regard, this study was conducted with the aim of comparing the costs of global inpatient services bills with their approved tariffs in Niknafs Obstetrics and Gynecology Hospital in Rafsanjan.

Materials and Methods: In this descriptive study, the population included all the invoices of hospitalized cases subjected to the global tariff in 2019 in Niknafs Hospital in Rafsanjan. The required data were collected from the patients' accounts and analyzed using descriptive statistics and SPSS 20 software.

Results: In 2019, out of the total inpatient services related to the obstetrics and gynecology group, 6 services subjected to the global tariffs were performed in Niknafs Obstetrics and Gynecology Hospital in Rafsanjan. A comparison of the average costs incurred in these services with their approved tariffs showed that in all of them, hospital costs were between $10.74 \%$ and $20.54 \%$ higher than the approved global tariffs. The highest difference (20.54\%) was related to cesarean section, and the lowest (10.74\%) was related to hysterectomy.

Conclusion: The results of this study showed that the global services of this hospital have no economic justification and global tariffs lead to losses of the hospital. Therefore, it is suggested that hospital officials focus more on managing the costs of global services, and approved tariffs be reviewed in a timely manner, commensurate with the growth of inflation and taking into account the different conditions of patients.

Key words: Cost comparison, Global tariff, Rafsanjan University of Medical Sciences

Funding: This study was not funded by anywhere.

Conflict of interest: None declared.

Ethical approval: The Ethics Committee of University of Semnan approved the study (IR.IAU.SEMNAN. REC.1399.002).

How to cite this article: Zare Askari A, Mir Mohammadkhani M, Shahab MR, Ebrahimian AA. Comparison of Global Inpatient Services Costs with Approved Tariffs in Niknafs Obstetrics and Gynecology Hospital in Rafsanjan in 2019: A Descriptive Study. J Rafsanjan Univ Med Sci 2022; 20 (10): 1117-28. [Farsi]

1- PhD Student in Healthcare Services Management, Semnan Branch, Islamic Azad University, Semnan, Iran, ORCID: 0000-00033791-8002

2- Associate Prof., Dept. of Epidemiology and Statistics, School of Medicine, Semnan University of Medical Sciences, Semnan, Iran, ORCID: 0000-0001-6251-7484

(Corresponding Author) Tel: (023) 33451336, Fax: (023) 33451336, E-mail: majidmirmohammadkhani@yahoo.com

3- Assistant Prof., Dept. of Economics, Semnan Branch, Islamic Azad University, Semnan, Iran, ORCID: 0000-0002-8761-355x

4-Associate Prof., Disasters and Emergencies Group, Paramedic School, Qom University of Medical Sciences, Qom, Iran, ORCID: 0000-0003-2665-0514

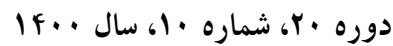

مجله دانشخاه علوم يزشكى رفسنجان 